\title{
International Justice, Intervention, and the Prevention of Evil
}

\author{
Bill Wringe
}

\section{Introduction}

Do the governments of Western liberal democracies have a right or, under certain circumstances, an obligation to intervene in the internal affairs of other states, perhaps by military means, in order to prevent the subjects of those states from suffering persecution from their own governments? This is not merely an abstract theoretical question. The idea that such an obligation exists was widely appealed to in justifying NATO intervention in the Kosovo crisis of 1999-2000. It also lies behind one widespread left-wing reaction to recent events in Afghanistan: namely that although the events of September 11, 2001 did not provide sufficient justification for American attacks on the Afghanistan, the Taliban's treatment of Afghan citizens and in particular of women did provide such a justification. In the event of Western military action in Iraq, we can expect similar arguments to be advanced as a means of gathering support from individuals who might otherwise be inclined to be suspicious of the motives for such intervention and pessimistic about its likely results.

To say that a certain right or obligation is widely believed to exist, or (which is not necessarily the same thing) that its existence is frequently appealed to in the course of political debate, is not to show that it does in fact exist. Still less is it to give any account of any grounds there might be for believing that it exists, or to say anything about the circumstances under which it applies, or any limitations which it might be subject to. The importance of the last of these issues is difficult to deny. To deal with it we need to have an account of what the right or obligation is based on. Since this is the sort of question which philosophers typically deal with, we seem to have a case for thinking that we have found an area in which philosophy has an important practical bearing. This provides, perhaps, some justification for engaging in philosophical discussion at a time and under circumstances in which it might otherwise seem inappropriate.

My aim in this chapter is to discuss a number of arguments for and against thinking that states have a right to intervene in the internal affairs of other states in order to prevent large-scale violations of human rights. I shall start by looking at one fairly intuitive argument which seems to support a very strong conclusion - namely that states sometimes have an obligation to intervene in the affairs of other states for these reasons. Although the argument seems cogent at first sight, I shall try to show that closer examination shows it to have serious weaknesses. I then look at two arguments that purport to show that such intervention is never justified. 
The first of these, which approaches the issue from a consequentialist perspective, is to be found in J.S. Mill's essay "A Few Words on NonIntervention." I shall argue that this argument fails because - like many consequentialist arguments, it does not take rights seriously enough.

I shall then examine John Rawls' recent book, The Law of Peoples, ${ }^{2}$ in order to see whether it provides a more satisfactory response to the question under discussion. Disappointingly, Rawls does not commit himself strongly to a clear view about the legitimacy of intervention. However, his official view seems to provide an argument against the existence of a right to intervene. Since this argument is not consequentialist in character, it is not vulnerable to the objections which undermined Mill's position. However, it suffers from weaknesses of its own. In particular, Rawls' account of how the obligations of states in the international field are to be grounded is unstable, because it makes morally arbitrary factors relevant to determining moral obligations. If the account is amended so as to avoid this objection, we end up with an argument that appears to show that a right of intervention might exist after all.

\section{The Intuitive Line of Argument}

For most of this chapter I shall be looking at what representatives of two central traditions in contemporary political philosophy can contribute to the debate about armed intervention. However, before doing so, I want to consider a line of thought which suggests that we can answer questions about the legitimacy of armed intervention without engaging in any high-level philosophical theorising. The suggestion is that we can see that armed intervention is likely to be not only morally justified, but also morally required under certain circumstances, provided we think carefully about what is involved in thinking about what it means to say that something is a human right.

One reason why the view is important is that it is widely accepted. Earlier I mentioned that the idea that armed intervention in the internal affairs of other states was widely accepted. What I did not say, but what seems nonetheless to be true, is that many of the people who hold it do not hold it unreflectively: they think that it is a belief which can be provided with some sort of rationale. The purpose of this section is to try to articulate and assess that rationale. If it is a good one, then there would be no need for any further philosophical reflection about whether armed intervention is justified.

Someone who holds a view of the sort that I shall be considering need not be guilty of holding a simplistic view about the morality of intervening in the affairs of other states. As I shall try to make clear, the reverse is true. The line of argument that I shall be considering is supposed to show that, under certain circumstances, intervention would be morally 
required. It might still be extremely difficult to tell whether these circumstances applied in any particular case where intervention might be proposed.

I shall begin by setting out and commenting on three constraints on the argument that I am trying to set out. The first constraint is that it should appeal to no controversial factual or ethical premises, beyond those that one is necessarily committed to in speaking of human rights at all. The second is that it should be capable of being set out using a minimum of philosophical technicalities. The third is that it should seem reasonably cogent, at least at first sight. The argument needs to meet these three constraints in order for the claim that it is the articulation of a widely held view to be at all plausible.

This is particularly obvious in the case of the first constraint. A widely held belief is unlikely to be based on premises that are not widely shared or on a line of reasoning that is obviously fallacious. Arguments that are obviously fallacious tend to be exposed as such, at least when they concern matters of public debate. Finally, the idea that the argument should employ a minimum of technical sophistication relies on the thought that philosophers tend to disagree among themselves in any case where philosophical sophistication is required. If philosophers cannot agree in such cases, no one else is likely to agree about them either So any line of argument that relies on a great deal of technical sophistication is for that reason likely to be controversial.

However, although the argument that I shall be examining is not supposed to require a great deal of philosophical technicality, there are two reasons why it is not entirely philosophically innocent either. The first is that it requires the use of one semi-technical philosophical notion - that of a prima facie obligation - which I shall explain in a moment. The second is that no argument that appeals to the notion of a human right can be philosophically innocent. We can distinguish two reasons why this is so. The first, and less interesting of the two, is this. The notions of rights in general and human rights in particular have attracted philosophical attention for several centuries. ${ }^{3}$ Unsurprisingly, different philosophers have given different analyses of what it is for someone to have any sort of a right, different accounts of what it is for a right to be a human right, and different lists of what rights are human rights. However, this does not matter for my purposes. I shall not be relying on any particular account of what rights are human rights - provided that it is agreed that there are some. Furthermore the claims that I am making about rights are intended (with one exception, which I shall note) to be as uncontroversial as possible.

A more significant reason why appeals to human rights cannot be entirely philosophically innocent is this. Someone who claims that the 
notion of a human right is coherent and that there are any human rights at all is committed to two substantive philosophical views. This is undeniable. However it is not important for my purposes, since I am not trying to put forward an argument which is supposed to establish on uncontroversial philosophical grounds that such rights do exist. Instead, I am interested in an argument that is supposed to show that once we do accept that the notion of a human right has some sort of content, we are committed to further views about the legitimacy of intervention. If I were then going to argue for a right of intervention based on such an appeal, it might be incumbent upon me to produce a philosophical defence of the notion of a human right. But in fact I shall be claiming that even if the appeal to human rights can be given an adequate grounding, it does not support the kind of view about intervention which it might at first sight seem to.

As I mentioned before the argument, I have in mind appeals to one semi-technical notion - that of a prima facie obligation. A prima facie obligation is an obligation that can be cancelled out under certain circumstances. For example, suppose I promise to meet you on the Charles Bridge at two o' clock tomorrow. I now have an obligation to be on the Charles Bridge at that time. But the obligation is only prima facie. There are many possible circumstances under which it would lapse. For example, if I were the only witness to a serious crime taking place and quarter to two on my way to our rendezvous, and took it upon myself to report what I had witnessed to the police straight away, I could not be condemned for missing our appointment. Nor could I if circumstances beyond my control made it physically impossible for me to be at the Charles Bridge at the right time - for example, if I were run down by a tram.

I can now set out the argument. It relies on a fairly uncontroversial analysis of the notion of a right as such, a particular interpretation of the phrase "human right," and two widely shared empirical premises. The analysis of the notion of a right $I$ have in mind is this: to say that someone has a right to something is not just to say that $\mathrm{s} /$ he ought to have it, but also that some other person or agent has a prima facie obligation to protect their enjoyment of it. ${ }^{4}$ Two comments on this analysis are worth making. The first is that where rights in general are concerned, the analysis does not say anything specific about which people the prima facie obligation devolves upon. The answer to this will depend on what sort of a right is being considered. Take my right, as a British citizen, to vote in a general election. The fact that I have such a right entails that if someone tries to prevent me from voting, there is at least one individual who has a prima facie obligation to prevent him or her from preventing me. But it does not entail that everyone in the world, or even every British citizen, or indeed every British citizen who is aware of my 
situation is under such an obligation. Furthermore, since the obligation is a prima facie obligation, there may be circumstances under which the obligation lapses.

So much for rights in general. However, not all rights can reasonably be regarded as human rights. My right to vote in British general elections is not a human right (though my right to some form of representation in government may be.) So in order to make any further progress we need to ask what is distinctive of human rights.

Human rights typically have three features. First, they have a high degree of generality. Second and relatedly, they are rights that I possess in virtue of being a human being, rather than in virtue of some more specific qualification. Third, they are rights whose observance plays a central role enabling us to live a recognisably human existence.

This third feature of human rights is somewhat vague. People might well differ about what features of a life make it recognisably human. Some accounts might make the exercise of a capacity for rationality central, while others might emphasise the satisfaction of a wider range of social, intellectual and emotional needs. ${ }^{5}$ Further differences about the circumstances under which we could expect such needs to be satisfied are also likely. These differences can clearly be expected to have an impact on exactly which rights are recognised as human rights; so if we were trying to derive a list of human rights, we would clearly have to give a full account of them. For the purposes of the current argument, though, this is unnecessary: the argument does not turn on some particular conception of what constitutes a recognisably human existence, but on the connection between the notion of a human right and some such connection.

The importance of human rights in enabling us to live a recognisably human life might reasonably be thought to have two consequences. First, the range of circumstances in which the prima facie obligation lapses is extremely narrow. In fact it is plausible that the only such circumstances are ones in which a particular agent is unable to carry out the obligation, and ones in which a conflict of rights is involved. Secondly the set of agents on whom the obligations devolve is as wide as it can possibly be. When we say that human rights are universal, we do not just mean that everyone possesses them, but also that everyone is under an obligation to uphold them, as far as is in his/her power.

These analyses of what is entailed by describing someone as having a right to something and of what is added by describing that right as a human right constitute the specifically philosophical elements of the argument that is supposed to demonstrate that states are sometimes under an obligation to intervene in the affairs of other states by military means in order to prevent human rights violations. However, they can only come close to doing so in the presence of two further premises. One is that 
warlike intervention in the affairs of a state can sometimes prevent violations of human rights. The second is that there are occasions on which no means short of warlike intervention can do so. Without the first premise, one could argue that states are released from the prima facie obligation to prevent human rights violations by the fact that they are incapable of doing so. Without the second premise one could argue that although they do have such an obligation, it is one which they ought to discharge by other, non-warlike means

The two non-philosophical premises of the argument are not entirely uncontroversial. Both can be disputed in particular cases. Arguments about whether they are true may constitute a great deal of the substance of moral debate about particular cases where intervention is proposed. So, as I noted before, someone who thinks that the argument sketched here is a good one need not necessarily have a simplistic or monolithic view of the rights and wrongs of intervention in particular cases. (Furthermore, someone might accept the claims about rights in general and human rights in particular that I have outlined above but dispute the further premises not only in particular cases, but in every case. So the analysis of the argument that I have outlined might even be acceptable to a pacifist. This would be true if his/her pacifism was based on the belief that, in any situation where human rights could be protected by warlike means, they could be protected equally by non-warlike means.) However, although the premises are not uncontroversial in themselves, most people who believe that armed intervention is justifiable in some cases will accept them as true. So they may reasonably figure in an articulation of a commonly held view. The only people who would deny them are people who do not hold that view.

Together with the claims about rights in general and human rights in particular that I outlined above, these two premises present us with an argument that seemingly shows that in some cases states will have an obligation to intervene militarily in the internal affairs of other states. Furthermore, it is reasonable to think that this argument, or something like it, underlies that common intuition that such intervention can be morally justified. It certainly satisfies the three criteria that I originally identified. It appeals to premises that are not highly controversial; it is reasonably compelling - at least at first sight; and it involves a minimum amount of philosophical technicality. (Someone might doubt this last claim because of the way in which the argument makes use of the notion of prima facie obligation. However, although this term may be on which does not belong to everyone's moral vocabulary, the idea that an apparent obligation may lapse or become less stringent under certain circumstances is one with which most of us are familiar). If the argument were watertight, there would be little else to say on the subject except by way of clarification. 
The argument is not, however, watertight. There are three main problems with it. One, as I have already pointed out, is that not everyone would agree that military interventions are an effective way of protecting human rights in any situation. Someone who takes this view could support it by pointing out that the success of most actual attempts at humanitarian intervention is highly contestable. Responding to this objection would involve a detailed examination of the historical record which would be out of place in the present context. Still, even if an adequate response could be made, two further problems would remain. The first concerns something that might be regarded as a philosophical technicality. In giving an account of the notion of a right earlier on, I appealed to Mill's idea that to say someone has a right to something is to say that society "ought to protect (them) in the possession of it." This idea is sufficiently widespread for the suggestion that it is part of what underlies a commonly held moral belief to be reasonable. Nevertheless, as I hinted earlier, it is not philosophically uncontroversial. An alternative account of rights exists. This is the account to be found in writers like Locke, who holds that to say that someone has a right to something is to say that that person is morally justified in attempting to punish another person who attempts to deprive them of the possession of it. ${ }^{7}$ On this view, someone's infringement of another person's rights does not impose any obligations on third parties, except perhaps the rather minimal obligation not to interfere with the individual who is trying to exact due punishment.

This objection might be met by showing that Locke's conception of a right is inadequate in this context. One reason for thinking so is that an examination of the context of Locke's account rights shows that it is designed to make sense of the idea that human beings might have had rights of certain kinds even if societies did not exist. However, one might argue that Locke's account of rights is suspect for that very reason: the idea that human beings might have had rights independently of their belonging to any society is incoherent. ${ }^{8}$ Someone who held this view would think that any account of rights that suggested otherwise could not be sustained. However, this line of argument is undermined by the reflection that to call a particular right a human right seems to be saying (among other things) that it is a right that they possess independently of belonging to any particular society. So this attempt to show that Locke's analysis of rights is not the right one to apply in the context of discussions of human rights seems self-stultifying.

A further problem with the argument we have been discussing is that it seems to involve a non sequitur. It relies on the idea that the claim that human rights confer prima facie obligations on everyone who is in a position to enforce them follows from the fact that human rights are important in enabling people to live a recognisably human life. This might 
seem fairly plausible at first sight. Still, it is not obvious that it is true or, if it is true why this should be so. As it stands, the argument seems to involve an important slide between the claim that a particular individual's human rights are important to that person and the claim that they are important to everyone.

This objection is not, however, decisive. One response to it can be found in the work of Alan Gewirth. ${ }^{9}$ Gewirth argues that if we see certain conditions as being necessary conditions for someone to be recognisable as an agent, then we are committed, on pain of inconsistency, to the idea that everyone should be able to benefit from similar conditions. On the face of it, though, there is not a very big difference between saying that certain conditions are necessary for someone to lead a recognisably human existence and saying that certain conditions are necessary conditions of agency. So if Gewirth's reasoning is correct, there is a way of bridging the gap between the idea that it is important for a particular individual that certain rights should be respected and the claim that it ought to be important for everyone else.

Two points need to be noted here. First, the idea that there is an inconsistency between seeing certain conditions as necessary for my being an agent and not seeing myself as committed to seeing that similar conditions are realised for other agents is one that requires considerable further support. Second, and more significantly, for my purposes the invocation of Gewirth's argument shows that we have moved out of the domain of pre-philosophical reflection and into that of explicit philosophical theorising. The idea that a cogent view about intervention can be arrived at without such theorising has been tried and found wanting.

Since this is so, I shall now look at what representatives of two central traditions in modern political philosophy have had to say about the question of intervention. I shall start by examining the consequentialist tradition, as represented by John Stuart Mill, and then turn to the contractualist tradition as represented by John Rawls. It will emerge that neither figure has an entirely a satisfactory view. We should not, however, despair: as I shall try to show at the end of the essay, Rawls' position can be modified in a way which enables it to escape the objections I shall be making.

\section{J.S. Mill's Consequentialist Argument for Non-Intervention}

One way in which one might hope to resolve questions about the rights and wrongs of one state's intervening in the internal affairs of another is by appeal to some form of consequentialist moral theory. For a consequentialist what matters when assessing the morality of a particular action is whether that action produces a positive balance of good over 
harm. ${ }^{10}$ Assessments of good and harm produced can be conceived of in terms of the balance of pain and pleasure (as in the classical utilitarians), ${ }^{11}$ of satisfied over unsatisfied preferences (as in more recent versions of consequentialism) ${ }^{12}$ or in the realisation or non-realisation of certain kinds of objective states of affairs. ${ }^{13}$

Arguments for the claim that one state ought to interfere in the affairs of another are often based on consequentialist assumptions. ${ }^{14}$ If these assumptions are correct they provide us with a powerful basis for arguing for intervention in any cases where it is reasonable to think that it will do more good than harm. They also give us grounds for ignoring objections based on a state's alleged right to treat its citizens as it sees fit, or a particular group's right to self-determination even in cases where this involves harm to the interests of individual members of those groups. For a consequentialist such considerations will be irrelevant. ${ }^{15}$

In the light of this, it is interesting that one of the founding fathers of modern consequentialist thought should have produced a general argument against intervention. In "A Few Words on Non-Intervention," " Mill puts forward a consequentialist case for one state's not intervening in the internal affairs of another. ${ }^{17}$ Mill wrote in the context of the struggles for national liberation that marked the middle of the nineteenth century. ${ }^{18}$ What he says might therefore be thought relevant to at least some, if not all, recent cases where intervention has been proposed.

Mill's essay can be read as a working out of some of the consequences for international relations of ideas that are developed in Utilitarianism and On Liberty. His argument depends on two empirical claims, and is subject to one important limitation. Mill relies upon two claims. First, a people that acquires independence from a foreign power with the help of a foreign power is unlikely to develop and retain free institutions of its own. Second, the development of such institutions is the best way of ensuring the long-term happiness of individuals who make up this people. The limitation is that the argument can only be held to apply to situations in which there is no prior foreign involvement.

For the purposes of this paper I shall take "free institutions" to be institutions which are stable, democratic, and constitutional. It may well be that twentieth-century liberals would not agree with Mill about exactly which institutions fit this description. An advantage to this interpretation is that, despite its potential anachronism, it leaves us with an argument that we can at least hope to take seriously. I shall also accept, for the sake of argument, Mill's claim that such institutions are the best way of ensuring the long-term happiness of the people who have to live under them. This assumption which seems to underlie many attempts at what modern commentators call "nation-building.,"19 
Even if we accept these assumptions, Mill's argument seems vulnerable to three lines of criticism. The first focuses on Mill's claim that a people is unlikely to develop or retain free institutions as a result of foreign intervention. This claim might have seemed plausible in the nineteenth century. It is much harder to defend it today. This is not because human nature has changed since the nineteenth century or because modern statesmen have more noble objectives than their predecessors, but because we can draw on wider historical experience than that which was available to Mill. Importantly, this wider experiences includes the constitutional settlements imposed on Germany and, more problematically, Japan in the wake of World War Two. Admittedly, these were constitutions imposed on countries that were defeated in wars of aggression. Nevertheless, modern Germany provides an example of a state developing free institutions not autonomously, but on the basis of foreign intervention - something that Mill regards as impossible or, at any rate, so unlikely a possibility as to be negligible. ${ }^{20}$

A second weakness in Mill's argument derives from his explicit limitation to cases where there is no prior foreign involvement. This limitation is problematic for two reasons. The first is that it is difficult to think of a recent case in which intervention in support of human rights has been advocated where there is no prior foreign involvement. This is certainly the case if we count as a case of foreign intervention the financial support provided by many governments and international agencies to governments with dubious human rights records. ${ }^{21}$ But Mill's limitation is also problematic because the question of whether foreign intervention is occurring or has occurred is not as straightforward as Mill takes it to be. ${ }^{22}$ One feature of many ethnic liberation struggles is precisely that they involve a claim on the part of one ethnic group to be subject to intervention by a foreign power - namely the power that has sovereignty over them. Tacit support for the status quo - for example, by governments that engage in alliances with states in which liberation struggles are taking place - might, too, be thought of as a form of international interference by those who are struggling against it.

A third objection relies on a line of argument that is familiar in much modern moral philosophy. ${ }^{23}$ It is that consequentialism wrongly neglects an important class of moral claims - namely claims of justice. The objection can be put like this. There are cases in which a concern with ensuring the best overall outcome of our actions involves disregarding individuals' rights. However, thinking about these cases in a more concrete manner suggests that consequentialists make the wrong moral judgement about them. For example, we do not think it right that an innocent individual should be punished in order to prevent rioting in which more than one individual will be killed. This is true even if this seems to 
be the action that will have the best consequences overall in terms of general happiness, preference satisfaction, or whatever a particular consequentialist theory instructs us to maximise. And the reason why we do not think that this is right is precisely because the person is innocent and that it is unjust to punish the innocent.

Mill's arguments against intervention seem to be subject to exactly the same sort of objection. An argument that says that it is wrong for one nation to intervene in the internal affairs of another because the long term prosperity and stability of a people requires that free institutions be attained autonomously seems to involve exactly the same trade-off between rights and consequences that is objectionable in the lynching case. However, there are a number of standard replies to the worry that consequentialist theories overlook considerations of justice. Whatever their merits in dealing with the lynching example, they do not provide us with a satisfactory view of the rights and wrongs of intervention.

One possible response to the lynching example is to refuse to engage with it. One rationale for doing so is this: in any actual case there are likely to be more options available than the ones with which the example presents us. Since this is so, the consequentialist can insist that the purpose of a moral theory is to tell us how we should act in the actual world and conditions like it, rather than in some Hollywood scriptwriter's fantasy, and that in the real world considerations of justice and consequences rarely if ever come into as stark conflict as the example suggests. However, this objection misses an important point. What really needs arguing against here is not how realistic the example is, but the principle that it is supposed to illustrate. The principle is that considerations of what people's rights are can provide us with a reason for doing something other than the action which has the best consequences overall.

Of course, the consequentialist could respond that in the lynching case, if we think hard about the long-term consequences of our actions, we will not be disposed to neglect people's rights after all. In the lynching case, one can argue that the consequences of having corrupt sheriffs can, in the long run, outweigh the benefits of avoiding riots. In the case of international intervention they can argue that the action which has the best overall consequences is the one that focuses on the sufferings of people in the here-and-now. Many people find this kind of response unconvincing. One reason for this is that even if it helps the consequentialist get the right answer in the lynching case, it does so for the wrong reason. ${ }^{24}$ On the consequentialist line the innocence of the accused man only plays an indirect role: it is because we think it might be bad for other people if he was punished, that we think he should not be. But this seems like a 
travesty of what we should actually think: namely that it is because this very person is innocent that it is wrong to punish him.

Even if, however, this defence of consequentialism can be made to work, it does not seem to provide us with a way of supporting Mill's position. We have provided a rationale for consequentialists to respect rights. If this rationale is not respected, the consequentialist position seems implausible. However, if it is respected, then the fact that failure to intervene in cases of human rights violations will involve the neglect of some people's rights seems to undermine the consequentialist case for nonintervention.

There are two final thoughts that need to be considered before we can move on from our discussion of Mill. So far, I have avoided distinguishing explicitly between what are known as "direct" and "'indirect" forms of consequentialism. Direct consequentialists hold that in any situation one should decide what is most likely to produce the best overall consequences of the sort favoured by the particular form of consequentialism under consideration. Indirect consequentialists hold that this is problematic for various reasons. What we should do instead is to come up with general policies which are likely to have good overall consequences, and then act in accordance with those, whatever their upshot seems likely to be in a particular case. ${ }^{25}$

Could careful attention of this distinction help to salvage Mill's argument? It is unlikely. Whether we take Mill to be a direct or an indirect consequentialist, the argument above presents him with a dilemma. If his view does not make respect for the rights of individuals into a relevant consideration when questions about intervention are under discussion, then it is implausible. If it does, then the considerations he raises about the value of free institutions can no longer be taken to be decisive even by his own lights.

Finally, and for the sake of completeness, I want to say something about Walker's claim that Mill's argument in the essay that I have been discussing should not be interpreted along consequentialist lines. ${ }^{26}$ Walzer argues that Mill should be taken as claiming that nations have a right to self-determination, and that interference by foreign powers necessarily undermines this right. ${ }^{27}$ Whatever the merits of this interpretation of Mill, two points are inescapable.

The first is this. If Mill did think that nations had such a right, (and it is worth noticing that he never expresses himself in exactly these terms), it does not follow that his account is to be interpreted along other than consequentialist lines. For in chapter five of Utilitarianism he gives a detailed account of how a consequentialist might be entitled to talk in terms of rights - an account that runs parallel to the indirect consequentialist one I have outlined above. But as I have argued, a 
defence of non-intervention on indirect consequentialist grounds cannot succeed - so Walzer's reference to a right of self-determination adds nothing to the argument.

However, it is possible that Walzer thinks - and believes that Mill thought - that nations have a right to self-determination that is not to be justified on consequentialist grounds. If so, it might provide a basis for an argument against intervention. Still, matters are not so clear cut as they might seem at first sight. For even if a right of self-determination of the sort which Walzer discusses did exist - and it is noticeable that he gives no clear rationale for thinking so - then it seems clear that the sorts of cases where intervention is relevant would involve a conflict of rights. Without a clearer account of what the right of self-determination is based on, it is difficult to know how this conflict should be resolved. But the suggestion that a state's rights to self-determination should always override the rights of individuals who are members of that state is not the only, or indeed the most attractive, answer to the question that this raises.

\section{John Rawls' Contractarian Defence of Non-Intervention}

In the last section I argued that a consequentialist argument for non-intervention in cases of human rights violations failed because it failed to acknowledge that there is a problem about trading off violations of rights against some form of long-term social good. This is an insight that has been exploited by recent writers in the contractarian tradition in ethics and political philosophy, most famously John Rawls. ${ }^{28}$ In light of this it is worth examining what authors in this tradition might have to say on the subject. Rather than attempting a survey of all the authors who have written on the topic who could be categorised as "contractarian," which would probably constitute a book-length project, I shall concentrate on one prominent contribution: John Rawls' recent book-length essay The Law of Peoples. ${ }^{29}$ It is worth saying at the outset that Rawls' work should not be taken as representative of the whole contractarian tradition. ${ }^{30}$ I have chosen to focus on it in part because of its depth and subtlety and in part because Rawls' reputation as one of the foremost political philosophers in the English-speaking world seems likely to ensure that it remains the focus of debate for a long time.

In The Law of Peoples, Rawls argues that there is a set of principles that liberal states should recognise as regulating the ways in which states deal with one another. These are the principles that would govern interactions if they were governed by an ideal of fairness, rather than the contingencies of power politics. We can discover what the principles are by imagining that a group of representatives of different states has been given the task of coming up with a set of principles to govern their interactions while not knowing which state they were 
supposed to be representing and asking what principles they could agree on. The purpose of making the individuals ignorant of which states they represent is supposed to ensure that the outcome of the negotiation is fair. No individual representative can get an especially favourable deal for their state by exploiting their power, global position, or natural resources, since they know nothing about these things. (It is irrelevant for Rawls' purposes that no actual individuals could be ignorant of these facts - a fair agreement, for Rawls' argument is one that has the same content as one which would be arrived at in this way. ${ }^{31}$ )

Rawls argues that these principles could also be accepted by representatives of what he calls "decent non-liberal states." This phrase is supposed to refer to non-aggressive states that have a system of law that protects certain human rights including the rights to life, liberty and what Rawls calls "formal equality," whose system of laws is in sufficiently good moral order to impose "bona fide moral duties and obligations on all persons within the states territory and whose system of law is administered by officials who are guided by "a sincere and not unreasonable belief.... that the law is....guided by a common good conception of justice." 32 Furthermore, because the principle one that would have to be acceptable to representatives of both liberal and decent non-liberal peoples, we can say something else that Rawls does not make explicit. These principles could be agreed by a group of representatives of both liberal and decent nonliberal peoples working under the same handicap of ignorance as in the first paragraph, together with the further complication that the representatives no longer know whether they are representing decent or non-decent peoples. However, the principles need not necessarily be acceptable to representatives of states who are neither decent nor liberal. Rawls' rationale for this is that liberal states are morally obliged to be tolerant of the moral views characteristic of decent non-liberal states, but not of those which are neither decent nor liberal.

In this chapter I shall not discuss whether Rawls is right to say that the principles of a Law of Peoples which is acceptable to liberals should also be acceptable to representatives of decent non-liberal states. ${ }^{33}$ Nor shall I discuss the full set of principles at which he arrives. Instead, I shall be concerned with the consequences of Rawls' views for questions about intervention, and with the plausibility of those consequences. This calls for some interpretative subtlety. Tensions in Rawls' position exist. They need to be resolved before it can be evaluated.

Much of what Rawls says suggests that there is a general presumption against one state's interfering in the internal affairs of another. ${ }^{34}$ This presumption is over-ridden in the case of what Rawls' calls 'outlaw states' - states that violate the principles that Rawls says could be agreed on in his thought experiment. ${ }^{35}$ Rawls argues that when such states 
present a threat to non-aggressive states, the latter have a right to counter these threats. But this leaves open the very real possibility of states that mistreat their own citizens but that do not engage in external aggression. Rawls' discussion of such states is restricted to two short footnotes. The first says that such states "may be subject to some form of intervention in severe cases, ${ }^{\prime 36}$ but does not specify what form this intervention may take. The second says that "forceful intervention" may be called for in cases where abuses are "egregious" and the "society does not respond to the imposition" of sanctions. ${ }^{37}$ Since we do not know what non-forceful sanctions Rawls considers legitimate, or what abuses are "egregious," this tells us little. Moreover, the footnotes seem to contradict the main body of the text, where we read, "Well-ordered states...wage war .... only against non-well-ordered states whose expansionist aims threaten the security and free institutions of well-ordered regimes." ${ }^{38}$

Given this apparent contradiction and given that Rawls provides little explicit argument for the view expressed in the body of the text and none for that in the footnote, we need to think about what Rawls' view ought to be. I shall now argue that given Rawls' view about how the content of the Law of Peoples ought to be fixed, he cannot endorse a principle of the sort that the footnotes suggest. A principle that licensed intervention in the case of human rights violations would not be endorsed by a group of representatives of both liberal and decent non-liberal states.

To see why this is so we need to look at the notion of a decent non-liberal people. Rawls' definition requires that such a people have a legal system that respects the rights of those who are subject to it. However it does not require the individual members of such peoples to have a commitment to the ideal of protecting human rights as such. In Rawls' view, a people whose legal system embodies the principle that the human rights of its subjects should be respected because they are members of a particular ethnic group, or have a particular national status, but are not concerned with advancing the cause of human rights qua human rights would still qualify as a decent people. So members of a group of representatives of both liberal and decent non-liberal societies who did not know which society they were representing could not assume a commitment to human rights on the part of that society. Without such a commitment, there is no reason to expect them to agree on a principle licensing intervention.

Still, one might think that a representative in such a situation would have no obvious reason for objecting to such a principle. But this is not true. One reason for objecting to it as a principle is that it is open to abuse by states trying to advance their own interests (and undermine those of other states) under cover of an intervention to protect human rights. This concern might be outweighed in the case of a group of 
representatives of liberal states by their shared commitment to human rights as a universal value. But if the representatives do not know whether their states have such a commitment then the concern cannot be outweighed in this way. So Rawls' position seems to imply that a law of peoples cannot incorporate a provision allowing for military intervention in the internal affairs of states which violate the rights of their citizens. Any such intervention, Rawls should say, will constitute a violation of the Law of Peoples.

\section{Conclusion: A Tentative Contractarian Defence of Intervention}

Rawls might well feel uncomfortable with the conclusion reached in the last paragraph. The direction of the argument suggests that by virtue of extending tolerance to decent non-liberal peoples, liberals are compelled to extend a form of de facto toleration of human rights abuses in states that do not meet Rawls' criteria of decency. But even if it was right to say that human rights abuses in one country could never justify military intervention, this seems like the wrong sort of justification. There is no compelling reason why liberals should take moral views which ex hypothesi they disagree with to affect their view of the legitimacy of intervention in this sort of case.

Furthermore, Rawls' account of how the principles of a Law of Peoples should be derived seems problematic at the theoretical level as well. Rawls' suggestion that Principles of the Law of Peoples need only be capable of being endorsed by representatives of liberal and decent nonliberal peoples brings into international ethics a kind of moral arbitrariness that we should try to avoid. As Rawls argues in A Theory of Justice, principles of justice should not allow rewards to depend on morally arbitrary qualities. But if this is true of the principles that govern a single society, then it should also be true of the principles that govern a society of societies. ${ }^{39}$ In the formulation of a Law of Peoples, excluding from consideration the voices of members of outlaw societies seems to import such arbitrariness. If anything is a morally arbitrary matter, the fact that one is unlucky enough to live under a government that is neither liberal nor decent is surely one. So, there are good grounds for thinking that Rawls should reconsider the way in which he formulates the Law of Peoples.

There are various ways in which such a reformulation might be attempted. Here I want to make one tentative suggestion and consider its implications for the issues that have been discussed in this chapter. Unlike other critiques of Rawls' view, this suggestion takes seriously the idea that provisions of the Law of Peoples should be arrived at by considering agreements that could be entered into by representatives of different states. 
The suggestion is as follows. In order that a provision of the Law of Peoples be acceptable it must be capable of being endorsed not just by representatives of liberal and decent non-liberal peoples but by representatives of all peoples, acting from behind a barrier of ignorance, which prevents them from knowing which people they are representing.

In order to see what the implications of this suggestion might be we need to say more about the notion of someone's being a "representative" of a particular society. A representative should be understood not to be a ruler of a given society in order to be a member of the people in question, handicapped by Rawlsian ignorance as to his exact position in the society. (This account of being a representative is Rawlsian in spirit, though not in detail. Rawls says relatively little about how the notion of a representative should be understood, although it is clearly crucial for understanding his view).

If we understand "representative"' in this sense, then we can see why a principle licensing intervention in cases of serious human rights violation might well be endorsed. For representatives will have to think of themselves as potential targets of human rights violations rather than as potential perpetrators, and it would be rational for such potential targets to make provision for their protection through the intervention of other states.

Of course, much more needs to be said. I have argued that if Rawls' account of the Law of Peoples is amended in the way I have suggested, then there will be some reason for expecting it to contain a principle licensing interventions to protect human rights. However, I have said nothing about the exact form such a principle might take, or how it might apply to particular cases of human rights violations. These are important questions, which I hope to address in future work, but they fall outside the scope of the present chapter.

\section{Notes}

${ }^{1}$ Mill, 1867.

${ }^{2}$ Rawls, 1999.

${ }^{3}$ Griffin, 2001, 307-310.

${ }^{4} \mathrm{Cf}$. Mill's account of the notion of a right in chapter 5 of Utilitarianism:

"When we call anything a person's right we mean that he has a valid claim on society to protect him in the possession of it" (Mill, 1991, 189). Mill need not necessarily quarrel with my claim in the text that these obligations may fall on particular individuals rather than society as a whole - a natural view would be that society can best discharge the 
obligation to which he refers by imposing special duties on particular individuals.

${ }^{5}$ Cf. Nussbaum, 2001, 401-5; Griffin, 2001, 310-2.

${ }^{6}$ Mill, 1991, 189.

${ }^{7}$ Locke, 1952, 5-7. Cf Nozick, 1972 for a recent statement of a similar view.

${ }^{8}$ Rousseau, 1968 seems to have held a view of this sort.

${ }^{9}$ Gewirth, 1996, 13-20.

${ }^{10}$ I here gloss over an important distinction between so-called "direct" and "indirect" forms of consequentialism. I return to this point below.

${ }^{11}$ For example, Bentham, 1987.

${ }^{12}$ For example, Smart, 1973.

${ }^{13}$ For example, Moore, 1903; Griffin 1986.

${ }^{14}$ For one recent example, see Doyle, 2001.

${ }^{15}$ Strictly speaking, this is only true for "direct consequentialists." Indirect consequentialists will have to make more nuanced judgements, which take into account the consequences of a general policy of non-interference.

${ }^{16}$ Mill, 1873.

${ }^{17}$ Walzer (in Walzer, 1977, 87-91) argues that Mill's essay should not be interpreted as a working out of the consequences of his general consequentialist views. I discuss his interpretation of Mill below.

${ }^{18} \mathrm{Cf}$. Walzer, 1977 for a similar emphasis on the context of Mill's essay.

${ }^{19}$ For more detail see Doyle, 2001.

${ }^{20}$ Cf. Doyle, 2001. Doyle also argues that the existence of the UN and its record of successful involvement in peace making undermine Mill's position.

${ }^{21}$ Cf. Pogge, 2001.

${ }^{22}$ Cf. Walzer, 1977, 96.

${ }^{23}$ A locus classicus is Rawls, 1972.

${ }^{24}$ This kind of objection is pushed by Bernard Williams. See, for example, Williams, 1985.

25 See Lyons, 1965 for a discussion of arguments for indirect consequentialism.

${ }^{26}$ Walzer, 1977, 87-88.

${ }^{27}$ Walzer, 1977, 88.

${ }^{28}$ Rawls, 1972 loc cit.

${ }^{29}$ Rawls, 1999.

${ }^{30}$ For examples of work in the contractarian tradition that suggests a different view of these issues, see Beitz, 1975; Pogge, 1987, 2001.

${ }^{31}$ See Rawls, 1980 for a discussion of how the procedure is supposed to work and why the outcome should be regarded as fair.

${ }^{32}$ Rawls, 1999, 64-7.

${ }^{33}$ See Pogge, 1994; Caney, 2002 for criticisms of this sort. 
${ }^{34}$ See Rawls, 1999, 37 for a clear statement of this point.

${ }^{35}$ Rawls, 1999, 84.

${ }^{36}$ Rawls, 1999, 90, footnote 1.

${ }^{37}$ Rawls, 1999, 94, footnote 6.

${ }^{38}$ Rawls, 1999, 94; italics mine.

${ }^{39}$ Rawls, 1972, 22-7.

\section{References}

Bentham, J. (1987), 'An introduction to the principles of morals and legislation', in: A. Ryan (ed.) Utilitarianism and other essays. Harmondsworth: Penguin.

Beitz, C. (1975), 'Justice and international relations', Philosophy and public affairs, 5: 360-89.

Caney, S. (2002), 'Cosmopolitanism and the law of peoples', Journal of political philosophy, 10: 95-123.

Doyle, M. (2001), 'The new interventionism', Metaphilosophy, 10: 21235.

Gewirth, A. (1996), The community of rights. Chicago: University of Chicago Press.

Griffin, J. (1986), Wellbeing. Oxford: Oxford University Press. - (2001), 'First steps in an account of human rights', European Journal of Philosophy 9: 306-327.

Locke, J. (1951), The second treatise of government. Indianapolis: Bobbs Merill.

Lyons, D. (1965), Forms and limits of utilitarianism. Oxford: Oxford University Press.

Mill, J.S. (1867), ‘A few words on non-intervention', in: Dissertations and discussions political, philosophical, and historical. London:

Longmans, Green, Reader and Dyer. 153-178.

- (1991), 'Utilitarianism', in: On liberty and other essays. Oxford: Oxford University Press.

Moore, G.E. (1903), Principia ethica. Cambridge: Cambridge University Press.

Nozick, R. (1974), Anarchy, state and utopia. Oxford: Oxford University Press.

Nussbaum, M. (2001), Upheavals of thought. Cambridge: Cambridge University Press. 
94 International Justice, Intervention, and the Prevention of Evil

Pogge, T. (1987), Realizing Rawls. Ithaca: Cornell University Press. - (1994), 'An egalitarian law of peoples', Philosophy and public affairs, 23: $195-224$.

- (2001), 'Priorities of global justice', Metaphilosophy, 32: 6-24. Rawls, J. (1999/1972), A theory of justice. Cambridge, MA: Belknap Press.

- (1980), 'Kantian constructivism in moral theory', Journal of philosophy, 77: 515-72.

- (1999), The law of peoples. Cambridge: Harvard University Press. Rousseau, J-J. (1968), On the social contract. M. Cranston (trans.) Harmondsworth: Penguin.

Smart, J. (1973), 'A defence of utilitarianism' in: J. Smart and B. Williams (eds.) Utilitarianism: for and against. Cambridge: Cambridge University Press.

Walzer, M. (1977), Just and unjust wars. New York: Basic Books.

Williams, B. (1985), Ethics and the limits of philosophy. London: Fontana Press. 